\title{
Analisis Pengaruh Keterlibatan Keluarga terhadap Kinerja Perusahaan di Indonesia
}

\author{
Santi Yopie ${ }^{1}$, Chrislin $^{2}$ \\ Universitas Internasional Batam ${ }^{1,2}$ \\ Santiyopie.uib@yahoo.com ${ }^{1}$, chrislin.lin@icloud.com²
}

*Corresponding Author

Diajukan : 12 Desember 2021

Disetujui : 17 Desember 2021

Dipublikasi : : 1 Januari 2022

\section{ABSTRACT}

Family businesses have steadily dominated the economy sector in recent decades. A number of scholars have focused on the link between management by family members and firm performance. However, the findings are not conclusive and vary. As a result, a re-examination is necessary. The goal of this research is to determine the possible influences caused by family presence, non-family shareholders, professional president directors, and founder-managed firms on firm performance, as well as the link between family presence and firm performance when family firm reputation is taken into the account. Firm performance was valued by measuring return on asset and equity, sales growth, and tobin's q. This study examined 600 samples consisting 120 family firms in manufacturing and service sectors on Indonesia's Stock Exchange beginning with the year 2016 - 2020. To make data analysis more straightforward, panel regression research (time series and cross-sectional data) was conducted utilizing PLS 3.0 software. The study results prove family presence, professional president directors, and foundermanaged firms have positive impact on firm performance. Meanwhile, non-family shareholders showed negative impact towards firm performance. Furthermore, the findings of this study also show the favorable impact of family presence on firm performance may be bolstered by family firm reputation.

Keywords: Family Presence; Family Reputation; Non-family Shareholders; Performance; Professional President Directors

\begin{abstract}
ABSTRAK
Perusahaan keluarga terus mendominasi sektor ekonomi dalam beberapa dekade terakhir. Sejumlah penelitian telah berfokus pada hubungan antara manajemen yang dikelola oleh anggota keluarga dan kinerja perusahaan. Namun, temuannya tidak konklusif dan bervariasi. Akibatnya, perlu dilakukan pemeriksaan ulang. Tujuan dari penelitian ini adalah untuk mengetahui kemungkinan pengaruh yang disebabkan oleh kehadiran keluarga, pemegang saham nonkeluarga, presiden direktur profesional, dan perusahaan yang dikelola pendiri terhadap kinerja perusahaan, serta hubungan antara kehadiran keluarga dan kinerja perusahaan ketika reputasi perusahaan keluarga diperhitungkan. Kinerja perusahaan dinilai dengan mengukur pengembalian aset dan ekuitas, pertumbuhan penjualan, dan tobin's q. Penelitian ini menguji 600 sampel yang terdiri dari 120 perusahaan keluarga di sektor manufaktur dan jasa di Bursa Efek Indonesia mulai tahun 2016 - 2020. Untuk mempermudah analisis data, dilakukan penelitian regresi panel (time series dan cross-sectional data) dengan memanfaatkan perangkat lunak PLS 3.0. Hasil studi membuktikan kehadiran keluarga, presiden direktur profesional, dan perusahaan yang dikelola pendiri memiliki dampak positif terhadap kinerja perusahaan. Sementara itu, pemegang saham non-keluarga menunjukkan pengaruh negatif terhadap kinerja perusahaan. Selanjutnya, temuan penelitian ini juga menunjukkan dampak yang menguntungkan dari kehadiran keluarga pada kinerja perusahaan dapat didukung oleh reputasi perusahaan keluarga.
\end{abstract}


Kata Kunci: Kehadiran Keluarga; Reputasi Keluarga; Pemegang Saham Non-keluarga; Kinerja; Presiden Direktur Profesional

\section{PENDAHULUAN}

Sejumlah penelitian telah memusatkan perhatian pada dampak keterlibatan keluarga terhadap kinerja perusahaan selama beberapa dekade terakhir (Mazagatos et al., 2016). Sejauh mana keluarga mengontrol aktivitas perusahaan sehari-hari dapat dinilai melalui keterlibatan anggota keluarga dalam manajemen (Liang et al., 2014). Dari tahun ke tahun, perusahaan keluarga juga semakin mendominasi pasar di sebagian besar negara, termasuk Indonesia (Gill \& Kaur, 2015). Mengingat pentingnya keterlibatan keluarga dalam manajemen pada kinerja perusahaan keluarga, perannya menarik banyak perhatian penelitian (Zattoni et al., 2015). Namun, sebagian besar fokus ini lebih diarahkan pada perusahaan-perusahaan dari Amerika dan Eropa, dengan sedikit atau tanpa adanya analisis yang berarti pada perusahaan keluarga dari negara-negara berkembang, seperti Indonesia (Ashwin et al., 2015).

Hingga saat ini, berdasarkan banyaknya penelitian tentang dampak partisipasi dan keterlibatan keluarga dalam manajemen terhadap keberhasilan kinerja perusahaan keluarga, hasil penelitian tidak pasti dan berbeda-beda. Bukti empiris menunjukkan bahwa keterlibatan keluarga dapat meningkatkan, memperburuk, atau bahkan memiliki pengaruh kecil pada kinerja perusahaan keluarga (Kim \& Gao, 2013). Hasil empiris yang bertentangan ini mungkin disebabkan oleh beberapa prediksi teoritis yang kontradiktif, inkonsistensi dalam metodologi, dan kurangnya perhatian pada faktor perusahaan yang dapat memoderasi hubungan antara keterlibatan keluarga dan kinerja perusahaan.

Di Indonesia, perusahaan keluarga memegang peranan penting. Hal ini dibuktikan dengan adanya kepemilikan keluarga yang dimiliki oleh lebih dari separuh pelaku usaha di Indonesia (Setiawan et al., 2016). Akan tetapi, studi yang mengkaji dampak keterlibatan keluarga terhadap kinerja perusahaan keluarga di Indonesia relatif masih terbatas. Seiring dengan semakin beragamnya hasil studi terkait pengaruh keterlibatan keluarga terhadap kinerja perusahaan keluarga, menjadi motivasi untuk melakukan pembuktian pengaruh keterlibatan keluarga terhadap kinerja perusahaan keluarga di Indonesia. Tujuan dari penelitian ini adalah untuk mengetahui pengaruh kehadiran keluarga, pemegang saham non-keluarga, presiden direktur profesional, dan perusahaan yang dikelola oleh pendiri terhadap kinerja perusahaan keluarga di Indonesia, diantaranya adalah Alkindo Naratama, Barito Pacific, Ciputra Development, dan 117 perusahaan terbuka keluarga lainnya. Lebih dari itu, penelitian ini juga bertujuan untuk mengetahui hubungan antara kehadiran keluarga dengan kinerja perusahaan ketika ada dukungan reputasi perusahaan keluarga.

\section{STUDI LITERATUR}

\section{Pengaruh Kehadiran Keluarga terhadap Kinerja Perusahaan}

Kehadiran anggota keluarga dapat dilihat melalui empat poin penting, yaitu adanya keterlibatan keluarga dalam manajemen, kepemilikan oleh anggota keluarga, posisi presiden direktur yang diduduki anggota keluarga, dan perusahaan yang dikelola oleh penerus keluarga (Santiago et al., 2019). Penelitian yang dilakukan oleh Gill \& Kaur (2015), González-cruz \& Cruz-ros (2015), Poutziouris et al. (2015), Gallucci et al. (2015), Mazagatos et al. (2016), dan Rienda et al. (2020) menyatakan kehadiran keluarga berpengaruh positif terhadap kinerja perusahaan. Artinya, ketika tingkat kehadiran anggota keluarga tinggi, maka kinerja perusahaan akan semakin bagus.

\section{$\mathrm{H}_{1}$ : Kehadiran Keluarga Berpengaruh Positif terhadap Kinerja Perusahaan}

\section{Pengaruh Pemegang Saham Non-keluarga terhadap Kinerja Perusahaan}

Kepemilikan dalam perusahaan terbuka ditandai dengan kepemilikan saham atas suatu perusahaan. Dalam sebuah perusahaan keluarga, tidak menutup kemungkinan adanya kepemilikan saham oleh anggota non-keluarga (Hiebl, 2015). Hasil penelitian Hiebl (2015) dan Mohammed (2018) menyimpulkan bahwa pemegang saham non-keluarga beroperasi lebih sesuai dengan stereotip prinsipal netral-risiko yang tersirat dalam filosofi agensi. Dalam perusahan keluarga, kehadiran pemegang saham non-keluarga dapat mempengaruhi kapasitas perusahaan 
untuk mencapai standar keberhasilan yang lebih tinggi. Sehingga, adanya kehadiran pemegang saham non-keluarga dapat mempengaruhi kinerja perusahaan pada arah yang positif.

\section{$\mathrm{H}_{2}$ : Pemegang Saham Non-keluarga Berpengaruh Positif terhadap Kinerja Perusahaan}

\section{Pengaruh Presiden Direktur Profesional terhadap Kinerja Perusahaan}

Posisi presiden direktur dalam sebuah perusahaan keluarga di Indonesia cenderung diwariskan kepada anggota keluarga melalui proses suksesi yang dilakukan dari generasi ke generasi (Yopie \& Itan, 2016). Namun, terkadang perusahaan keluarga dapat memutuskan untuk tidak mewariskan posisi presiden direktur kepada anggota keluarga dengan berbagai alasan (Khanin et al., 2020). Sehingga, posisi presiden direktur diberikan kepada anggota non-keluarga, atau lebih umum disebut sebagai presiden direktur profesional. Penelitian yang dilakukan oleh Yopie \& Itan (2016) menemukan bukti empiris mengenai pengaruh positif dari presiden direktur non-keluarga pada tingkat pengambilan risiko kewirausahaan yang kemudian akan mempengaruhi kinerja perusahaan secara positif.

\section{$\mathrm{H}_{3}$ : Presiden Direktur Profesional Berpengaruh Positif terhadap Kinerja Perusahaan}

\section{Pengaruh Perusahaan yang dikelola Pendiri terhadap Kinerja Perusahaan}

Dalam sebuah perusahaan, pendiri merupakan aset karena telah bersama perusahaan sejak awal pembentukannya. Sehingga, pendiri dapat memberikan tingkat antusiasme yang tinggi dan visi yang besar, serta arah yang jelas untuk masa depan perusahaan (Nimtrakoon, 2015). Namun, hasil studi Nimtrakoon (2015), Ullah \& Zhang (2016), dan Hassan Khan \& Siddiqui (2020) menyatakan bahwa perusahaan yang dikelola oleh pendiri justru berkinerja buruk dan cenderung meremehkan rekan-rekan perusahaan. Sehingga, perusahaan yang dikelola oleh pendiri berdampak negatif terdahap kinerja perusahaan.

\section{$\mathrm{H}_{4}$ : Perusahaan yang dikelola Pendiri Berpengaruh Negatif terhadap Kinerja Perusahaan}

\section{Reputasi Perusahaan Keluarga sebagai Moderasi Pengaruh Kehadiran Keluarga terhadap Kinerja Perusahaan}

Reputasi perusahaan keluarga adalah persepsi perusahaan oleh pemangku kepentingan yang dinilai oleh beberapa unsur esensi, yaitu persentase dewan, persentase kepemilikan, nama patronim, usia, dan ukuran perusahaan (Santiago et al., 2019). Hasil studi Santiago et al. (2019) membuktikan dengan adanya moderasi reputasi perusahaan keluarga dapat memperkuat pengaruh kehadiran keluarga terhadap kinerja perusahaan secara positif.

$H_{5}$ : Reputasi Perusahaan Keluarga Memperkuat Pengaruh Positif Kehadiran Keluarga terhadap Kinerja Perusahaan

\section{METODE}

Studi ini bersifat kuantitatif karena jenis data yang dikumpul dan diolah berupa angka dan menggunakan jenis data time series dan cross-sectional karena mengamati perusahaan keluarga lebih dari satu periode dan lebih dari satu sektor industri. Adapun syarat dan kriteria yang diwajibkan dalam penelitian ini, yaitu: satu keluarga sekurang-kurangnya memiliki kepemilikan dua puluh lima persen, hubungan keluarga ditandai sekurang-kurangnya dua pemegang saham yang memiliki nama keluarga yang sama atau sekurang-kurangnya satu anggota dewan memiliki nama keluarga yang sama dengan pemilik pengendali (Massis et al., 2013), perusahaan keluarga sektor manufaktur dan jasa yang terdaftar dalam BEI (Bursa Efek Indonesia), sudah menerbitkan laporan tahunan dan laporan keuangan dari 2016 - 2020, dan perusahaan masih berjalan pada saat penelitian dilakukan. Berdasarkan syarat dan kriteria tersebut, diperoleh 120 perusahaan keluarga, sehingga sampel yang diuji berjumlah 600 data.

Tabel 1. Pengukuran Variabel

\begin{tabular}{|c|c|}
\hline Variabel & Pengukuran \\
\hline Kinerja Perusahaan & Dependen \\
\hline
\end{tabular}


Owner: Riset \& Jurnal Akuntansi

e-ISSN : 2548-9224 | p-ISSN : 2548-7507

Volume 6 Nomor 1, Januari 2022

DOI : https://doi.org/10.33395/owner.v6i1.593

\begin{tabular}{|c|c|}
\hline & Return on Asset $(R O A)=\frac{\text { Lawa Bersin }}{\text { Total Aktiva }} \times 100 \%$ \\
\hline & Return on Equity $($ ROE $)=\frac{\text { Laba Bersih }}{\text { Total Ekuitas }} \times 100 \%$ \\
\hline & Sales Growth $=\frac{\text { Penjualan Bersih }(t)-\text { Penjualan Bersih }(t-1)}{\text { Penjualan Bersih }(t-1)} \times 100 \%$ \\
\hline & Tobin's $Q=\frac{(\text { Nilai Kapitalisasi Pasar Saham }+ \text { Total Kewajiban })}{\text { Total Aktiva }} \times 100 \%$ \\
\hline \multicolumn{2}{|r|}{ Independen } \\
\hline \multirow[t]{4}{*}{ Kehadiran Keluarga } & Keterlibatan Keluarga $=$ Persentase keterlibatan keluarga dalam manajemen \\
\hline & Kepemilikan Keluarga = Persentase saham milik keluarga \\
\hline & Presiden Direktur Keluarga = Tidak (0); Iya (1) \\
\hline & Perusahaan yang dikelola Penerus = Tidak (0); Iya (1) \\
\hline $\begin{array}{l}\text { Pemegang Saham Non- } \\
\text { keluarga }\end{array}$ & Persentase saham yang dimiliki oleh anggota non-keluarga \\
\hline $\begin{array}{l}\text { Presiden Direktur } \\
\text { Profesional }\end{array}$ & Tidak (0); Iya (1) \\
\hline $\begin{array}{l}\text { Perusahaan yang dikelola } \\
\text { Pendiri }\end{array}$ & Tidak (0); Iya (1) \\
\hline \multicolumn{2}{|r|}{ Moderasi } \\
\hline \multirow{5}{*}{$\begin{array}{l}\text { Reputasi Perusahaan } \\
\text { Keluarga }\end{array}$} & Dewan Keluarga = Persentase jumlah anggota keluarga dalam dewan \\
\hline & Kepemilikan Keluarga = Persentase saham yang dimiliki keluarga \\
\hline & Nama Patronim = Tidak (0); Iya (1) \\
\hline & Usia perusahaan = Logaritma natural usia perusahaan \\
\hline & Ukuran = Logaritma natural jumlah karyawan perusahaan \\
\hline \multicolumn{2}{|r|}{$\underline{\text { Kontrol }}$} \\
\hline Ukuran Perusahaan & Logaritma natural jumlah karyawan perusahaan \\
\hline Usia Perusahaan & Logaritma natural usia perusahaan \\
\hline Industri Perusahaan & Manufaktur (0); Jasa (1) \\
\hline Lokasi Perusahaan & Luar Jabodetabek (0); Dalam Jabodetabek (1) \\
\hline Edukasi Pemilik & $\begin{array}{l}\text { SMA atau lebih rendah (1); Gelar Diploma (2); Gelar S1 (3); Gelar S2 (4); } \\
\text { Gelar S3 (5) }\end{array}$ \\
\hline
\end{tabular}

\section{Statistik Deskriptif}

\section{HASIL}

Tabel 2. Hasil Uji Statistik Deskriptif - Variabel Non-dummy

\begin{tabular}{|l|r|r|r|r|r|}
\hline \multicolumn{1}{|c|}{ Variabel } & N & \multicolumn{1}{c|}{ Minimum } & Maksimum & \multicolumn{1}{c|}{ Rata-rata } & $\begin{array}{c}\text { Standar } \\
\text { Deviasi }\end{array}$ \\
\hline ROA & 600 & $-1,88$ & 1,10 & 0,03 & 0,13 \\
\hline ROE & 600 & $-11,57$ & 3,39 & 0,03 & 0,61 \\
\hline SalesGrowth & 600 & $-3,97$ & 10,51 & 0,08 & 0,76 \\
\hline TobinsQ & 600 & 0,15 & 14,99 & 1,51 & 1,40 \\
\hline FIM & 600 & 0,00 & 0,85 & 0,27 & 0,20 \\
\hline FamOwn & 600 & 0,25 & 0,95 & 0,61 & 0,19 \\
\hline NonFamOwn & 600 & 0,05 & 0,75 & 0,39 & 0,18 \\
\hline FamOnBoard & 600 & 0,00 & 0,67 & 0,27 & 0,19 \\
\hline Age & 600 & 7,00 & 69,00 & 32,23 & 12,62 \\
\hline
\end{tabular}


Owner: Riset \& Jurnal Akuntansi

e-ISSN : 2548-9224 | p-ISSN : 2548-7507

Volume 6 Nomor 1, Januari 2022

DOI : https://doi.org/10.33395/owner.v6i1.593

\begin{tabular}{|l|r|r|r|r|r|}
\hline Size & 600 & 19,00 & 121953,00 & 5022,03 & 13462,71 \\
\hline Valid N(listwise $)$ & 600 & & & \\
\hline
\end{tabular}

Sumber: Data Pengolahan SMART PLS (2021)

Sesuai dengan yang ditampilkan pada Tabel 2, sampel data yang berhasil dikumpulkan berjumlah 600. Diantara semua indikator diuji, yang mencapai angka negatif adalah return on asset and equity dan sales growth. Angka return on asset yang negatif merupakan tanda ketidakmampuan perusahaan untuk menggunakan asetnya secara efisien dalam menghasilkan pendapatan perusahaan. Angka return on equity yang mencapai negatif merupakan pertanda efisiensi kinerja perusahaan yang kurang baik. Namun, sebagian besar perusahaan yang mencapai angka negatif dapat disebabkan oleh biaya yang timbul akibat perbaikan perusahaan, seperti restrukturisasi manajemen.

Dari 600 sampel yang diuji, terdapat indikator yang mencapai angka 0, yaitu keterlibatan anggota keluarga dalam manajemen dan dewan anggota keluarga. Hal ini menandakan bahwa dari sampel yang diuji, terdapat perusahaan keluarga yang sepenuhnya tidak dikelola keluarga dan terdapat juga perusahaan keluarga yang sepenuhnya tidak memiliki anggota keluarga sebagai dewan.

Tabel 3. Hasil Uji Statistik Deskriptif - Variabel Dummy (1)

\begin{tabular}{|l|r|r|r|}
\hline \multicolumn{1}{|c|}{ Variabel } & \multicolumn{1}{c|}{ Tidak } & \multicolumn{1}{c|}{ Iya } & \multicolumn{1}{c|}{ Jumlah } \\
\hline FamCEO & 284 & 316 & 600 \\
\hline SMC & 386 & 214 & 600 \\
\hline CProf & 321 & 279 & 600 \\
\hline FMC & 498 & 102 & 600 \\
\hline PatName & 575 & 25 & 600 \\
\hline Industry & 240 & 360 & 600 \\
\hline Location & 104 & 496 & 600 \\
\hline
\end{tabular}

Sumber: Data Pengolahan SMART PLS (2021)

Penelitian ini menggunakan beberapa data dummy. Berdasarkan Tabel 3, dapat disimpulkan bahwa 316 sampel perusahaan keluarga dikelola oleh presiden direktur keluarga, 386 sampel posisi presiden direktur tidak disuksesi kepada anggota keluarga, 321 sampel perusahaan keluarga tidak dipimpin oleh presiden direktur profesional, 498 sampel perusahaan tidak dipimpin secara langsung oleh pendiri perusahaan, hanya 25 sampel perusahaan keluarga yang menjadikan nama keluarga sebagai nama perusahaan, 360 sampel perusahaan keluarga bergerak di sektor jasa, dan sebanyak 496 sampel perusahaan keluarga yang beroperasi di Jabodetabek.

Tabel 4. Hasil Uji Statistik Deskriptif - Variabel Dummy (2)

\begin{tabular}{|c|c|c|c|c|c|c|}
\hline & $\begin{array}{c}\text { SMA atau } \\
\text { lebih } \\
\text { rendah }\end{array}$ & Diploma & S1 & S2 & S3 & Jumlah \\
\hline CEOEdu & 92 & 5 & 317 & 181 & 5 & 600 \\
\hline
\end{tabular}

Sumber: Data Pengolahan SMART PLS (2021)

Variabel dummy terakhir dalam penelitian ini diukur oleh tingkat pendidikan presiden direktur perusahaan. Berdasarkan 600 sampel yang diuji, sebanyak 92 sampel presiden direktur berpendidikan SMA atau lebih rendah, 5 sampel presiden direktur berpendidikan Diploma, 317 sampel presiden direktur bergelar S1, 181 sampel presiden direktur bergelar S2, dan 5 sampel presiden direktur bergelar S3. Hal ini membuktikan mayoritas presiden direktur perusahaan keluarga di Indonesia bergelar S1. 


\section{Uji Validitas}

Tabel 5. Hasil Uji Validitas

\begin{tabular}{|l|r|r|r|r|r|r|r|r|r|r|r|r|}
\hline & $\begin{array}{c}\text { CEO } \\
\text { Edu }\end{array}$ & Indus & Loc & Size & Age & FIM & FP & ME & NFO & FMC & CP & FR \\
\hline CEO Edu & 1,00 & & & & & & & & & & & \\
\hline Indus & 0,37 & 1,00 & & & & & & & & & & \\
\hline Loc & 0,34 & 0,25 & 1,00 & & & & & & & & & \\
\hline Size & 0,08 & $-0,22$ & 0,11 & 1,00 & & & & & & & & \\
\hline Age & $-0,11$ & $-0,34$ & 0,05 & 0,08 & 1,00 & & & & & & & \\
\hline FIM & $-0,01$ & $-0,13$ & $-0,04$ & $-0,08$ & $-0,02$ & 0,46 & & & & & & \\
\hline FP & $-0,04$ & 0,02 & $-0,01$ & 0,15 & $-0,04$ & 0,11 & 0,55 & & & & & \\
\hline ME & 0,09 & 0,02 & 0,01 & $-0,15$ & $-0,07$ & $-0,02$ & 0,03 & 1,00 & & & & \\
\hline NFO & 0,25 & 0,31 & 0,16 & 0,05 & $-0,08$ & $-0,83$ & $-0,07$ & 0,02 & 1,00 & & & \\
\hline FMC & $-0,41$ & $-0,22$ & $-0,07$ & $-0,02$ & 0,09 & $-0,35$ & $-0,11$ & 0,00 & $-0,09$ & 1,00 & & \\
\hline Cprof & 0,32 & 0,28 & 0,29 & $-0,08$ & $-0,16$ & 0,35 & 0,06 & 0,08 & 0,14 & $-0,42$ & 1,00 & \\
\hline FR & 0,13 & $-0,10$ & 0,06 & 0,68 & $-0,07$ & 0,29 & 0,22 & 0,07 & $-0,29$ & $-0,10$ & 0,02 & 0,44 \\
\hline
\end{tabular}

Sumber: Data Pengolahan SMART PLS (2021)

Untuk memenuhi kriteria validitas diskriminan, variabel harus mempunyai korelasi tertinggi pada dirinya. Berdasarkan hasil uji, semua sampel terbukti telah memenuhi kriteria validitas diskriminan.

\section{Uji Hipotesis}

Tabel 6. Hasil Uji Hipotesis

\begin{tabular}{|l|r|r|r|}
\hline & Sample Mean $(\boldsymbol{M})$ & \multicolumn{1}{|c|}{ T Statistics } & \multicolumn{2}{|c|}{ P Values } \\
\hline CEOEdu & $-0,14$ & 2,54 & 0,01 \\
\hline Industry & 0,08 & 1,21 & 0,23 \\
\hline Location & $-0,02$ & 0,35 & 0,73 \\
\hline Size & 0,05 & 0,41 & 0,68 \\
\hline Age & 0,01 & 0,07 & 0,95 \\
\hline FIM & 0,06 & 0,00 & 0,10 \\
\hline ME & 0,04 & 0,24 & 0,81 \\
\hline FMC & 0,03 & 0,03 & 0,98 \\
\hline NonFamOwn & $-0,06$ & 1,28 & 0,20 \\
\hline Cprof & 0,14 & 0,30 & 0,77 \\
\hline FR & 0,18 & 0,93 & 0,35 \\
\hline
\end{tabular}

Sumber: Data Pengolahan SMART PLS (2021)

Pada penelitian ini, hipotesis yang diajukan berjumlah lima buah. Berdasarkan hasil uji $\left(\mathrm{H}_{1}\right)$, diketahui variabel kehadiran keluarga memiliki pengaruh positif terhadap variabel kinerja perusahaan sebesar 0,06. Artinya, jika tingkat kehadiran keluarga semakin tinggi, maka kinerja perusahaan semakin meningkat. Hipotesis pertama dapat diterima.

Hasil uji $\left(\mathrm{H}_{2}\right)$ membuktikan variabel pemegang saham non-keluarga mempunyai pengaruh negatif sebesar 0,06 terhadap variabel kinerja perusahaan. Hal ini berarti tingkat pemegang saham non-keluarga yang semakin tinggi akan menyebabkan semakin menurunnya kinerja perusahaan. Sehingga, hipotesis kedua tidak dapat diterima.

Hasil uji $\left(\mathrm{H}_{3}\right)$ menunjukkan variabel presiden direktur profesional mempunyai pengaruh positif terhadap variabel kinerja perusahaan sebesar 0,14 . Hal ini menandakan bahwa dengan 
adanya kehadiran presiden direktur profesional dapat meningkatkan kinerja perusahaan. Sehingga, hipotesis ketiga dapat diterima.

Hasil uji $\left(\mathrm{H}_{4}\right)$ mengungkapkan variabel perusahaan yang dikelola pendiri mempunyai pengaruh positif sebesar 0,03 terhadap variabel kinerja perusahaan. Hal ini menunjukkan bahwa perusahaan ketika dikelola oleh pendiri, akan meningkatkan kinerja perusahaan. Sehingga, hipotesis keempat tidak dapat diterima.

Hasil uji $\left(\mathrm{H}_{5}\right)$ menyatakan variabel moderasi reputasi perusahaan keluarga mempunyai pengaruh positif sebesar 0,04 terhadap hubungan kehadiran keluarga dan kinerja perusahaan. Artinya, reputasi perusahaan keluarga dapat memperkuat hubungan positif kehadiran keluarga terhadap kinerja perusahaan. Sehingga, hipotesis kelima dapat diterima.

\section{PEMBAHASAN \\ Pengaruh Kehadiran Keluarga terhadap Kinerja Perusahaan}

Berdasarkan hasil data pengolahan dari 120 perusahaan keluarga Indonesia, semakin dominan kehadiran keluarga dapat menghasilkan dampak yang semakin baik terhadap kinerja perusahaan. Kehadiran keluarga ini melibatkan tingginya tingkatan keterlibatan anggota keluarga dalam manajemen perusahaan, dominan jumlah saham yang dimiliki anggota keluarga, presiden direktur yang diduduki anggota keluarga, dan suksesi posisi presiden direktur kepada anggota keluarga generasi selanjutnya. Faktor-faktor esensi ini ketika semakin dominan akan memiliki dampak yang baik terhadap kinerja perusahaan secara keseluruhan.

Hasil analisis sependapat dengan Gill \& Kaur (2015), Poutziouris et al. (2015), Gallucci et al. (2015), González-cruz \& Cruz-ros (2015), Mazagatos et al. (2016), dan Rienda et al. (2020) yang berpendapat bahwa kinerja perusahaan akan semakin baik ketika adanya kehadiran anggota keluarga, baik melalui keterlibatan keluarga dalam manajemen, kepemilikan oleh anggota keluarga, posisi presiden direktur yang diduduki anggota keluarga, ataupun perusahaan yang dikelola oleh penerus keluarga.

\section{Pengaruh Pemegang Saham Non-keluarga terhadap Kinerja Perusahaan}

Berdasarkan hasil data pengolahan dari 120 perusahaan keluarga di Indonesia, ketika saham perusahaan secara dominan dimiliki oleh pemangku kepentinan non-keluarga dapat memperburuk kinerja perusahaan keluarga di Indonesia. Hal ini memberi bukti bahwa kepemilikan anggota nonkeluarga memiliki kepentingan, arah, visi dan misi yang berbeda dengan anggota keluarga. Artinya, dalam menentukan masa depan perusahaan kerap terjadi perbedaan pendapat antara anggota keluarga dan non-keluarga, sehingga dapat memperburuk kinerja perusahaan.

Hasil analisis membuktikan bahwa semakin banyak pemegang saham non-keluarga akan menyebabkan semakin menurunnya kinerja perusahaan. Hasil ini tidak berjalan lurus dengan penelitian oleh Eelderink (2014), Isakov \& Weisskopf (2014), Hiebl (2015), dan Mohammed (2018) yang berpendapat bahwa kehadiran pemegang saham non-keluarga dapat mempengaruhi kapasitas perusahaan untuk mencapai standar keberhasilan yang lebih tinggi.

\section{Pengaruh Presiden Direktur Profesional terhadap Kinerja Perusahaan}

Berdasarkan hasil data pengolahan dari 120 perusahaan keluarga di Indonesia, mayoritas posisi presiden direktur diduduki anggota keluarga. Namun, hasil pengolahan membuktikan bahwa presiden direktur profesional justru lebih memberikan dampak baik terhadap perusahaan. Hal ini dikarenakan presiden direktur profesional dapat memberikan pendapat yang tidak bergantung pada prinsip keluarga dan lebih berani mengambil risiko dibandingkan dengan presiden direktur keluarga. Sehingga, presiden direktur profesional dapat memimpin kinerja perusahaan ke arah yang lebih baik.

Hasil analisis sependapat dengan penelitian oleh Huybrechts et al. (2013) dan Yopie \& Itan (2016). Presiden direktur non-keluarga akan berpengaruh positif terhadap kinerja perusahaan karena memiliki keberanian dalam pengambilan risiko kewirausahaan.

\section{Pengaruh Perusahaan yang dikelola Pendiri terhadap Kinerja Perusahaan}


Berdasarkan hasil data pengolahan dari 120 perusahaan keluarga di Indonesia, pendiri memang benar merupakan aset yang berharga bagi perusahaan. Pendiri perusahaan merupakan pemangku kepentingan yang telah hadir sejak awal pembentukan perusahaan. Pendiri memiliki tingkat antusiasme dan visi yang besar, serta mengetahui bagaimana arah yang jelas untuk masa depan perusahaan. Sehingga, jika perusahaan dipimpin oleh pendiri dapat menghasilkan kinerja perusahaan yang optimal.

Hasil analisis ini bertentangan dengan penelitian oleh Nimtrakoon (2015), Ullah \& Zhang (2016), dan Hassan Khan \& Siddiqui (2020). Berdasarkan hasil penelitian terdahulu, pendiri kerap memiliki tingkat ego yang lebih tinggi, sehingga sering menindas rekan kerja lainnya. Hal ini terbukti tidak berlaku di perusahaan keluarga Indonesia.

\section{Reputasi Perusahaan Keluarga sebagai Moderasi Pengaruh Kehadiran Keluarga terhadap Kinerja Perusahaan}

Reputasi perusahaan keluarga dalam penelitian ini dinilai berdasarkan persentase dewan, persentase kepemilikan, nama patronim, usia, dan ukuran perusahaan. Berdasarkan hasil data pengolahan dari 120 perusahaan keluarga di Indonesia, semakin dominan unsur keluarga dalam hal reputasi akan memberi arah yang semakin positif terhadap hubungan kehadiran keluarga dan kinerja perusahaan secara keseluruhan. Artinya, semakin baik reputasi perusahaan keluarga, maka dapat memperkuat hubungan positif kehadiran keluarga dan kinerja perusahaan. Hasil analisis ini sependapat dengan penelitian Santiago et al. (2019).

\section{KESIMPULAN}

Hasil dari analisis dan pembahasan dapat menyimpulkan (1) kehadiran keluarga mendukung pengaruh positif terhadap kinerja perusahaan keluarga di Indonesia, (2) presiden direktur professional mendukung pengaruh positif terhadap kinerja perusahaan keluarga di Indonesia, dan (3) perusahaan yang dikelola pendiri mendukung pengaruh positif terhadap kinerja perusahaan keluarga di Indonesia. Artinya, semakin banyak kehadiran keluarga dalam perusahaan, hadirnya presiden direktur profesional, dan ketika perusahaan dikelola secara langsung oleh pendiri dapat meningkatkan kinerja perusahaan. Sedangkan, (4) pemegang saham non-keluarga dinyatakan berpengaruh negatif terhadap kinerja perusahaan. Artinya, ketika kepemilikan oleh non-keluarga semakin dominan, maka akan menurunkan kinerja perusahaan. Lebih dari itu, hasil penelitian ini juga dapat membuktikan (5) reputasi perusahaan keluarga dapat memperkuat pengaruh positif kehadiran keluarga terhadap kinerja perusahaan. Artinya, ketika dimoderasi oleh reputasi perusahaan keluarga yang baik, maka pengaruh kehadiran keluarga terhadap kinerja perusahaan akan semakin positif.

\section{REFERENSI}

Ashwin, A. S., Krishnan, R. T., \& George, R. (2015). Family firms in India: family involvement, innovation and agency and stewardship behaviors. Asia Pacific Journal of Management, 32(4), 869-900. https://doi.org/10.1007/s10490-015-9440-1

Blanco-Mazagatos, V., de Quevedo-Puente, E., \& Delgado-García, J. B. (2016). How agency conflict between family managers and family owners affects performance in wholly familyowned firms: A generational perspective. Journal of Family Business Strategy, 7(3), 167177. https://doi.org/10.1016/j.jfbs.2016.07.003

Eelderink, G. J. (2014). Effect of ownership structure on firm performance. University of Twente Faculty, 1-77.

Gallucci, C., Santulli, R., \& Calabrò, A. (2015). Does family involvement foster or hinder firm performance? The missing role of family-based branding strategies. Journal of Family Business Strategy, 6(3), 155-165. https://doi.org/10.1016/j.jfbs.2015.07.003

Gill, S., \& Kaur, P. (2015). Family Involvement in Business and Financial Performance: A Panel 
Data Analysis. 40(4), 395-420. https://doi.org/10.1177/0256090915605756

González-cruz, T. F., \& Cruz-ros, S. (2015). When does family involvement produce superior performance in SME family business? 弥. Journal of Business Research. https://doi.org/10.1016/j.jbusres.2015.10.124

Hassan Khan, M. S., \& Siddiqui, D. A. (2020). The Impact of Entrepreneur-CEOs on Company Performance. SSRN Electronic Journal. https://doi.org/10.2139/ssrn.3681289

Hiebl, M. R. W., Hiebl, M. R. W., Cirillo, A., Romano, M., Ardovino, O., Laforet, S., Development, E., Gaur, S. S., Bathula, H., \& Singh, D. (2015). Article information :

Huybrechts, J., Voordeckers, W., \& Lybaert, N. (2013). Entrepreneurial Risk Taking of Private Family Firms: The Influence of a Nonfamily CEO and the Moderating Effect of CEO Tenure. Family Business Review, 26(2), 161-179. https://doi.org/10.1177/0894486512469252

Isakov, D., \& Weisskopf, J. P. (2014). Are founding families special blockholders? An investigation of controlling shareholder influence on firm performance. Journal of Banking and Finance, 41(1), 1-16. https://doi.org/10.1016/j.jbankfin.2013.12.012

Khanin, D., Rakshit, A., Mahto, R. V., \& McDowell, W. C. (2020). An Ongoing race: family CEOs vs. non-family CEOs. International Entrepreneurship and Management Journal, 16(3), 1043-1063. https://doi.org/10.1007/s11365-019-00602-8

Kim, Y., \& Gao, F. Y. (2013). Does family involvement increase business performance? Familylongevity goals' moderating role in Chinese family firms. Journal of Business Research, 66(2), 265-274. https://doi.org/10.1016/j.jbusres.2012.08.018

Liang, X., Wang, L., \& Cui, Z. (2014). Chinese Private Firms and Internationalization: Effects of Family Involvement in Management and Family Ownership. Family Business Review, 27(2), 126-141. https://doi.org/10.1177/0894486513480885

Massis, A. De, Kotlar, J., Campopiano, G., \& Cassia, L. (2013). Journal of Family Business Strategy Dispersion of family ownership and the performance of small-to-medium size private family firms. Journal of Family Business Strategy, 4(3), 166-175. https://doi.org/10.1016/j.jfbs.2013.05.001

Mohammed, A. M. (2018). The impact of ownership structure on firm performance: Evidence from Jordan. Academy of Accounting and Financial Studies Journal, 22(5), 1-4. https://doi.org/10.11648/j.ijafrm.20180301.12

Nimtrakoon, S. (2015). 기사 (Article) 와 안내문 (Information) [. The Eletronic Library, 34(1), $1-5$.

Poutziouris, P., Savva, C. S., \& Hadjielias, E. (2015). Family involvement and firm performance: Evidence from UK listed firms. Journal of Family Business Strategy, 6(1), 14-32. https://doi.org/10.1016/j.jfbs.2014.12.001

Rienda, L., Claver, E., \& Andreu, R. (2020). Family involvement, internationalisation and performance: An empirical study of the Spanish hotel industry. Journal of Hospitality and Tourism Management, 42(August 2019), 173-180. https://doi.org/10.1016/j.jhtm.2020.01.002

Santiago, A., Pandey, S., \& Manalac, M. T. (2019). Family presence, family firm reputation and perceived financial performance: Empirical evidence from the Philippines. Journal of 
Family Business Strategy, 10(1), 49-56. https://doi.org/10.1016/j.jfbs.2019.02.002

Setiawan, D., Bandi, B., Kee Phua, L., \& Trinugroho, I. (2016). Ownership structure and dividend policy in Indonesia. Journal of Asia Business Studies, 10(3), 230-252. https://doi.org/10.1108/JABS-05-2015-0053

Ullah, S., \& Zhang, D. (2016). The Influence of Founder Status on Firm Performance: Empirical Evidence from Canadian IPO Firms. International Journal of Economics and Finance, $8(11), 134$. https://doi.org/10.5539/ijef.v8n11p134

Yopie, S., \& Itan, I. (2016). CEO-Family vs. CEO-Nonfamily: Who is a Better Value Creator in Family Business? Journal of Applied Management Accounting Research, 14(2), 37-46.

Zattoni, A., Gnan, L., \& Huse, M. (2015). Does Family Involvement Influence Firm Performance? Exploring the Mediating Effects of Board Processes and Tasks. XX(X), 130. https://doi.org/10.1177/0149206312463936 